\title{
RAPD ANALYSIS OF GENETIC VARIABILITY IN A MULTIPROVENANCE BASE POPULATION OF Eucalyptus grandis HILL EX MAIDEN ${ }^{1}$
}

Susi Meire Maximino Leite ${ }^{2}$, Édson Seizo Mori ${ }^{3}$, Celina Ferraz do Valle ${ }^{4}$, César Augusto Valencise Bonine ${ }^{4}$ e Celso Luís Marino

\begin{abstract}
This study aimed to evaluate the genetic variability among individuals of a base population of Eucalyptus grandis and to build a molecular marker database for the analyzed populations. The Eucalyptus grandis base population comprised 327 individuals from Coff's Harbour, Atherton and Rio Claro. A few plants came from other sites (Belthorpe MT. Pandanus, Kenilworth, Yabbra, etc.). Since this base population had a heterogeneous composition, the groups were divided according to geographic localization (latitude and longitude), and genetic breeding level. Thus, the influence of those two factors (geographic localization and genetic breeding level) on the genetic variability detected was discussed. The RAPD technique allowed the evaluation of 70 loci. The binary matrix was used to estimate the genetic similarity among individuals using Jaccard's Coefficient. Parametric statistical tests were used to compare within-group similarity of the means. The obtained results showed that the base population had wide genetic variability and a mean genetic similarity of 0.328 . Subgroup 3 (wild materials from the Atherton region) showed mean genetic similarity of 0.318. S.P.A. (from Coff's Harbour region) had a mean genetic similarity of 0.322 and was found to be very important for maintenance of variation in the base population. This can be explained since the individuals from those groups accounted for most of the base population ( $48.3 \%$ for it). The base population plants with genetic similarity higher than 0.60 should be phenotypically analyzed again in order to clarify the tendency of genetic variability during breeding programs.
\end{abstract}

Keywords: Molecular markers, forest tree breeding and population genetics.

\section{VARIABILIDADE GENÉTICA ATRAVÉS DA TÉCNICA RAPD DE UMA POPULAÇÃO-BASE MULTIPROCEDÊNCIAS DE Eucalyptus grandis HILL EX MAIDEN}

\begin{abstract}
RESUMO-Este estudo visou avaliar a variabilidade e distância genética dentro de uma população-base de melhoramento genético de Eucalyptus grandis. A avaliação da variabilidade genética tem como objetivos principais analisar a base genética da população-base e montar um banco de dados marcadores moleculares da população em análise. Essa população é formada por 327 indivíduos, principalmente das procedências de Coff's Harbour, Atherton e Rio Claro. Devido à heterozigosidade natural dessa população, ela pode ser dividida em diversas subpopulações, de acordo com a latitude e longitude de origem; e dentro de subpopulações, em função do grau de melhoramento genético já realizado do material analisado no Brasil. Isso permitiu avaliar quanto da variabilidade detectada dentro da população-base foi devido a esses fatores: procedência e grau de melhoramento. A aplicação da técnica RAPD permitiu avaliar 70 locos polimórficos, que foram analisados utilizando-se o coeficiente de Jaccard, o que resultou em matrizes de similaridade genética entre os indivíduos. Os dados de similaridade genética posteriormente foram submetidos à análise estatística. Os
\end{abstract}

\footnotetext{
${ }^{1}$ Recebido em 24.01.2007 e aceito para publicação em 22.08.2008.

${ }^{2}$ Centro de Ciências Agrárias da Universidade de Marília (UNIMAR). E-mail: <sleite-fca@ unimar.br>.

${ }^{3}$ Departamento de Produção Vegetal, UNESP/FCA, Cx.P. 237, 18603-970 Botucatu, SP. E-mail:<esmori@ fca.unesp.br> ${ }^{4}$ VcpFlorestalSA,PesquisaeDesenvolvimento, RodSP255,Km41,24.LuisAntonio,SP.E-mail:<celinafv@vcp.com.br>e<cesar.bonine@ $@$ vcp.com.br>.

${ }^{5}$ Departamento de Genética da Universidade Estadual Paulista Júlio de Mesquita Filho (UNESP). E-mail:<clmarino@ibb.unesp.br>.
} 
dados indicaram que a população-base apresenta ampla base genética, com média de similaridade genética de 0,328. O subgrupo denominado Região 3, composto por material selvagem da macrorregião de Atherton, juntamente com material de APS da macrorregião de Coff's Harbour, foi um dos que mais contribuíram para a ampla base genética da população-base. Foi possível detectar diferença estatística entre as populações selvagens das procedências de Atherton e Coff's Harbour, assim como entre essas procedências e a de Rio Claro.

Palavras-chave: Marcadores moleculares, melhoramento genético florestal e genética de populações.

\section{INTRODUCTION}

In Brazil, silviculture research started in the early twentieth century. Its main target was the production of wood to meet the demand at that time due to increasing natural devastation and the difficulty of replacement with natural species. Silviculture is mainly based on exotic genus such as Pinus and Eucalyptus and is now known as Intensive Silviculture. Brazil has an invaluable germplasm bank of the genus Eucalyptus and several breeding programs of more than 30 years duration that may be considered mature for future decisions (FERREIRA and SANTOS, 1997).

The application of molecular markers to the study of genetic diversity in base populations has gained ground as an important support to genetic breeding programs (KREMER et al., 1994; SEBBENN and SEOANE, 2005). The base populations are characterized for crossings of superior individuals aimed at obtaining gene groups or gene sets by recombination in order to find new combinations of interest.

Molecular information on genetic similarity may allow keeping genetic variability in the course of an improvement program to evaluate the redundancy and deficiency of germplasm collections. This is possible through the generation of data on the efficiency of the collection process, and maintenance, management and expansion of a bank germplasm (PHILLIPS et al., 1993; NEWBURRY and FORD- LLOYD, 1993).

Random Amplified Polymorphism DNA (RAPD) has been widely used in the genus Eucalyptus to identify clones (LANGE et al., 1993), to study genetic diversity to obtain better hybrid combinations (MURO-ABAD et al., 2005), and to construct molecular maps (GRATTAPAGLIA and SEDEREROFF, 1994) and QTLs maps (GRATTAPAGLIA et al., 1995), to evaluate genetic variability between individuals (CAIXETA et al., 2003).

Therefore, in the present study we used molecular markers (RAPD) as a tool to evaluate the genetic variability in the base populations comprising a Eucalyptus grandis improvement program. This information, combined with morphological data, will help infer the genetic variability of the base population.

\section{MATERIALAND METHODS}

Plant material: The plant material comprised 327 individuals of E. grandis that compose a base population of forest tree breeding from a forestry company in the state of São Paulo in Brazil.

Those individuals were selected from low $\left(16^{\circ}\right.$ $\left.19^{\circ} \mathrm{S}\right)$ and high latitude $\left(25^{\circ}-30^{\circ} \mathrm{S}\right)$ populations in Australia (Table 1). Since variability was studied in the base population as a whole, it was also possible to evaluate the groups formed by the individuals that comprised it. Thus, the parameters latitude and longitude were also used as a joint criterium to separate those regions termed Atherton region and Coff's Harbour region.

The heterogeneous composition of base population also allowed to study other levels of comparison, such as: (1) wild material (without selection), and improved material (with selection in Brazil) from Atherton and Coff's Harbour; (2) breeding populations (from Seed Production Areas - S.P.A. and Clonal Seed Orchards - CSO) from improved Coff's Harbour material; and (3) sub-population from wild Atherton (Table 1). The aim of such comparisons was to verify possible differences in the genetic basis of sub-populations as a result of differences in the degree of genetic improvement and provenances.

Wild Atherton accesses were divided into three sub-groups (sub-group 1, sub-group 2, and sub-group 3 ) according to the provenance. Sub-group 1 was composed by individuals from Paluma and Mount Spec, two localities from the same provenance. Sub-group 2 was composed by individuals from Mount Frazer and Mount Lewis. Sub-group 3 was composed by Atherton, Rifle Range, Wondecla, Mount Oandanus, Revenshoe, Wild River, Herberton, Tinaroo Creek Road, and Davis Creek Road provenances. 
Table 1 - Sub-populations forming the population base.Number of plants per each sub-population, percentage of participation of these sub-populations in the base population, latitudes and longitudes from the Australia regions where they were collected

Tabela 1 - Composição das subpopulações que formam a população-base. Seguem o número de indivíduos de cada subpopulação, a porcentagem de participação na população-base e as latitudes e longitudes dos locais de origem na Austrália

\begin{tabular}{|c|c|c|c|c|}
\hline Sub-populations & $\mathrm{N}^{\circ}$. of plants & Participation (\%) & Latitude E & Longitude S \\
\hline Rio Claro & 17 & 5.2 & $25^{\circ}$ to $30^{\circ}$ & $152^{\circ} 39^{\prime}$ to $153^{\circ} 08^{\prime}$ \\
\hline Wild sub-group 1-Atherton region & 13 & 4.0 & $18^{\circ} 52^{\prime}$ to $19^{\circ} 03^{\prime}$ & $146^{\circ} 07^{\prime}$ to $146^{\circ} 08^{\prime}$ \\
\hline Wild sub-group 2-Atherton region & 14 & 4.3 & $16^{\circ} 35^{\prime}$ & $145^{\circ} 16^{\prime}$ to $145^{\circ} 17^{\prime}$ \\
\hline Wild sub-group 3-Atherton region & 68 & 20.8 & $17^{\circ} 03^{\prime}$ to 17 o $42^{\prime}$ & $145^{\circ} 24^{\prime}$ to $145^{\circ} 37^{\prime}$ \\
\hline Wild material - Coff's Harbour region & 19 & 5.8 & $25^{\circ}$ to $30^{\circ}$ & $152^{\circ} 39^{\prime}$ to $153^{\circ} 08^{\prime}$ \\
\hline S.P.A. - Atherton region & 08 & 2.4 & $16^{\circ}$ to $19^{\circ}$ & $145^{\circ} 16^{\prime}$ to $146^{\circ} 08^{\prime}$ \\
\hline S.P.A. - Coff's Harbour region & 158 & 48.3 & $25^{\circ}$ to $30^{\circ}$ & $152^{\circ} 39^{\prime}$ to $153^{\circ} 08^{\prime}$ \\
\hline C.S.O. - Coff's Harbour region & 30 & 9.2 & $25^{\circ}$ to $30^{\circ}$ & $152^{\circ} 39^{\prime}$ to $153^{\circ} 08^{\prime}$ \\
\hline
\end{tabular}

The study also included a total of 17 individuals selected from Rio Claro Experimental Station, seed lot 2094 (ex Companhia Paulista de Estradas de Ferro), São Paulo-Brazil. The seeds from this lot were collected in Australia from a single tree with excellent size and vigor, known as "Vincent tree" (Ferreira, personal oral communication).

DNA extraction, RAPD reaction and electrophoresis: The procedures used were those proposed by Williams etal. (1990) and modified by Grattapaglia and Sederoff (1994) for Eucalyptus grandis species.

Selection of Primers: Arbitrary primer screening was performed with 27 ten-base primers (Operon Technologies Inc., Alameda, California). For selection of the polymorphic primers, the OPN kit and part of the OPX kit (OPX1- OPX7) were used. Only polymorphic loci between 5,001 and 1,500 bp, according to Ladder $1 \mathrm{~Kb}$ standard were considered.

Statistical Analysis: RAPD is a dominant marker scored considering band presence (1) and band absence (0). Only polymorphic loci were analyzed with the NTSYS v.2.02 (Rohlf, 1993). The similarity matrix, obtained by Jaccard's coefficient, was used in analysis of variance, and the Tukey test when necessary, performed by the SAS software (Statistical Analysis System) to $5 \%$ of significance.

\section{RESULTS AND DISCUSSION}

\subsection{Markers}

From 27 primers screened (kit OPN and OPX from 1 to 7$), 14.8 \%$ did not present any amplified product and $11.1 \%$ did not show clear results, thus hindering loci evaluation; $22.2 \%$ showed up to two polymorphic loci; and $51.8 \%$ showed higher polymorphism, with an average of 5 polymorphic loci per primer. The most polymorphic one was OPX7, with 8 assessable polymorphic loci. Grattapaglia and Sederoff (1994) obtained similar results with a population map of $E$. grandis. In the present work, from a total of 128 polymorphic RAPD loci, only 70 loci with better quality of amplification were analyzed, corresponding, on average, to approximately one marker for $22 \mathrm{cM}$ of the linkage map for the species.

\subsection{Statistical Analysis of groups}

The analysis among individuals in the regions Atherton and Coff's Harbour showed no significant difference between the genetic similarities in these regions (Table 2), showing that both materials have genetic variability. Since individuals of different levels of improvement were found within population of these regions, the difference between Coff's Harbour and Atherton was more evident when wild materials are compared.

When comparing the wild materials from both Atherton and Coff's Harbour regions, it was possible to see significant differences, with the individuals of the Atherton population being less similar among each other (genetic similarity mean $=0.327, \mathrm{n}=95$ ) than those of Coff's Harbour (genetic similarity mean $=0.345$, $n=19$ ) (Table 2). These results indicate that the Atherton region is also an interesting alternative for future seed collections, while many Brazilian reforestation companies dedicated to reforestation with Eucalyptus traditionally selected material from Coff's Harbour. In addition, the Coff's Harbour material proved to be less adapted to the environment where it was introduced in some aspects, such as being more susceptible to cancer in some regions of Brazil (Moura et al., 1992).

R. Árvore, Viçosa-MG, v.32, n.6, p.961-967, 2008 
Table 2 - Coefficient of variation (C.V.\%) and Tukey test analysis (significant at 5\%) of the comparisons between the different sub-populations

Tabela 2 - Coeficiente de variação (C.V.\%) e resultados do teste de Tukey (a 5\% de significância) das comparações entre as diferentes subpopulações

\begin{tabular}{lc}
\hline \multicolumn{1}{c}{ Sub-population } & Genetic similarity mean \\
\hline Rio Claro & $0.416 \mathbf{a}$ \\
Coff's Harbour region & $0.329 \mathbf{b}$ \\
Atherton region & $0.325 \mathbf{b}$ \\
\hline Wild sub-group 1- Atherton region & 0.388 a \\
Wild sub-group 2- Atherton region & $0.339 \mathbf{b}$ \\
Wild sub-group 3- Atherton region & $0.318 \mathbf{c}$ \\
\hline Coff's Harbour wild material & $0.345 \mathbf{a}$ \\
Atherton wild material & $0.327 \mathbf{b}$ \\
\hline Coff's HarbourS.P.A. & $0.322 \mathbf{a}$ \\
Coff's Harbour Wild material & $0.345 \mathbf{b}$ \\
\hline Coff's Harbour S.P.A. & $0.322 \mathbf{a}$ \\
Coff's Harbour C.S.O. & $0.363 \mathbf{b}$ \\
\hline Atherton improved population & 0.319 a \\
Atherton wild material & $0.327 \mathbf{a}$ \\
\hline
\end{tabular}

Values followed by a common letter indicate that the treatments did not differ at $5 \%$ by the Tukey test.

The high mean genetic similarity found among individuals from Rio Claro (0.416) not only showed their lower genetic variability but also their monoprogenic history. Although the recombination that took place after the introduction of this material in Brazil might have favored an increase in variability, the Rio Claro material is still quite inferior in terms of genetic variability, compared to the remaining sampled material, significantly differing from both Coff's Harbour and Atherton regions.

Nevertheless, Rio Claro is one of the most utilizedprovenances in forest tree breeding by large private paper and pulp companies in Brazil, mainly in clonal programs, because the plants show high vigor and productivity. However, that material has a reduced genetic variability caused by the high degree of inbreeding among individuals (half-sib descendants), and high rust incidence (Puccinia psidii) problems observed in many companies (MELLO et al., 1997).

Comparisons between wild and improved subpopulations from both regions were made when assessing possible variability loss after generations of improvement. Although wild sub-populations are not composed by the same individuals that originated from the improved sub-population, they can be used as reference regarding the variability level found in the original region, since they originated in the same provenance and thus present the same basic genetic material. According to the results, the Seed Production Area (S.P.A.) improved populations were superior in variability to the wild sub-populations from both regions, Atherton and Coff's Harbour. However, only in the Coff's Harbour region the difference was significant at 5\% level. Similar results were obtained by Pigato and Lopes (2001) in four generations of Eucalyptus urophylla with continued improvement of these materials. The higher similarity mean observed among wild sub-population individuals could be explained by the fact that: 1) the wild natural material was compared to a smaller number of related plants; 2) natural populations are under human pressure; 3) crossing chances are higher in breeding fields than under natural conditions because original barriers, such as poor distribution of the individuals within the population, high distance between individuals, and exploration of areas normally used for seed collection are not found. These factors lead to the conclusion that inbreeding reduces the variability between individuals. When plants are introduced, recombination is favored by reduced distance between individuals. Recombination is a balanced way of restoring population structure, as well as previously affected variability, what could explain why breeding materials showed higher genetic variability. The fact that Coff's Harbour region is where most factors causing structural inbalance are found could explain the higher difference between wild and S.P.A. sub-populations.

The fact is that the majority of the wild sub-population individuals are half-sibs, which contributed to a genetic variability bottleneck. It was observed that when similarity 
between individuals within group was taken by excluding only one individual from each family, there was an increment of $2.08 \%$ in variability, meaning a similarity decrease from 0.345 to 0.338 . The exclusion of one individual from each family was not sufficient for the new group to present variability higher than that of the S.P.A. material (mean of 0.322 ) but allowed the estimation of genetic variability loss by one selection of half-sibs. However, the selection of half-sibs should be conducted only when no other option is available or when the material is not designed for recombination in tree breeding programs, such as commercial plantation cloning.

Wild material from the Atherton region available for analysis in this base population is also made up of a reduced number of individuals ( 8 ). This is because only plants from Australian high latitude regions were introduced. Low latitude regions have recently been included in forest tree breeding programs developed by private companies. Those individuals are part of recombination of 17 elite trees from Australia that underwent low intensity selection in a S.P.A. At this level of improvement, recombination is greatly favored, leading to increased variability.

The genetic similarity results obtained for that group emphasize the role played by recombination in forest tree breeding programs in promoting the use of variability, further supporting the notion that data on genetic similarity between individuals may be used to establish S.P.A.s, which would be more adequate for adaptation in different environments. Similar results were obtained by Xavier et al. (1997) who concluded that before making any intervention through intensive selection to establish Seed Orchards (S.O.), it is necessary to improve local adaptation through rapid mass selection cycles in S.P.As, or even in Seed Collection Areas (S.C.As). The practice allows creating local races adapted to different edaphoclimatic conditions involved in a breeding program.

In order to examine the genetic variability losses along the selection process, two different breeding levels were compared for the Coff's Harbour material: a lower improvement selection intensity (S.P.A.) and a higher improvement selection intensity (C.S.O.). The comparison made possible to observe a reduction of $11.3 \%$ in genetic variability between two different improved populations. Clonal Seed Orchard material presented high genetic erosion occurring in only one generation of high selection intensity. In the base population, variability was reduced by $9.6 \%$. The participation of the C.S.O. sub-population in the base population was only $9.2 \%$ (Table 1) and therefore that reduction did not affect its general variability. The maintenance of this material in the base population also shows an advantage, i.e., a putative increase in the alleles frequency related to interesting silvicultural characteristics, as a consequence of the high selection intensity applied to those characteristics. On the other hand, the participation of S.P.A. in the base population was much more expressive (48.3\%) and, consequently, the similarity mean found within S.P.A. was very close to the total base population.

Wild Atherton material was divided into three subgroups (sub-group 1, sub-group 2, and sub-group 3) according to location (Table 1). Sub-group 3 showed the highest variability among individuals, with a mean of 0.318 . The superiorityof this region in genetic variability could be attributed to the more adequate climate and altitude conditions for E. grandis species and higher forest density. The population species structure in the region is more balanced due to a higher pollen flow allowed in these conditions, encouraging higher variability.

Sub-group 3 differed significantly at $5 \%$ level of significance from the similarity average found in sub-groups 1 and 2. Sub-group 1 region has large forest fragmentation, which can lead to an increment in inbreeding rate. This can be explained by the low variability found in sub-group 1. Another hypothesis is that subgroup 1 has been poorly sampled due to the difficulty in collecting seeds from an area that is less homogeneous and less structured

Sub-group 2 shows an intermediate genetic similarity of 0.339 , significantly different from sub-groups 1 and 3. Latitudes lower than $17^{\circ}$, as is the case of this subgroup, is adverse to adjustment to a denser forest, leading to the formation of forest fragments, which change the structure of the population due to pollination difficulty. Despite these factors, the genetic population structure is still better than in region 1 .

The analysis of the 327 individuals composing the base population showed higher level of similarity than that observed by Gaiotto et al. (1997). These authors worked with 121 families in a population of E. Urophylla,

R. Árvore, Viçosa-MG, v.32, n.6, p.961-967, 2008 
evaluated by 23 loci RAPD, obtaining an average of 0.6 similarity between individuals, which was considered high by the authors. Thus, the value of 0.328 obtained among individuals of the base population of $E$. grandis suggests that it shows broad genetic variability.

The results in the present study can serve as guidelines for the establishment of strategies for seed collection introduction in Brazil. The data can also be used to evaluate similar genotypes in the population base, so that individuals with high genetic similarity can be assessed in terms of their silvicultural characteristics of interest. In fact, they can only continue being part of the base population if sharing a similar aspect.Thus, an arbitrary similarity value (0.4) was chosen. Individuals showing that particular value or higher ones would undergo silvicultural evaluation within the base population. Forty-two groups, corresponding to 84 individuals, presented similarity higher than 0.4. The suggestion is that from each group of two individuals, one can be chosen to remain in base population. The chosen individual would be the one with better silvicultural traits. Reducing the number of individuals of the base population, with variability still maintained, allows a reduction of the permanent area, reducing the costs and producing gains for selection.

\subsection{Genetic analysis and crossing guidance}

Baril et al. (1997) demonstrated that it is possible to use data such as genetic distance as indicators for determination of crossings in Eucalyptus breeding programs. Analysis of similarity matrix, performed for 327 individuals representing the total base population, indicates that several could be crossing candidates based on the genetic distance among them. Those individuals were outstanding since they presented $0 \%$ of similarity at the evaluated loci. The use of genetic distance as a parameter to select the best individuals for crossing is based on the combination ability between morphologically contrasting paternal lines that will result in a superior hybrid. Since molecular markers produce a larger amount of information, they are important tools for selection of the best crossings.

The results of this study indicate that the phenotypic selection performed was efficient in obtaining genetic gain and maintaining the genetic variability of loci not involved by selection, except when applying high intensities of selection.

R. Árvore, Viçosa-MG, v.32, n.6, p.961-967, 2008

\section{ACKOWLEDGEMENTS}

The authors thank Votorantim Celulose and Paper S.A. for the financial support.

\section{REFERENCES}

BARIL, C. P. et al. Structure of the specific combining ability between two species of Eucalyptus. I. RAPD data. Theoretical and Applied Genetics, v.94, n.6/7, p.796-803,1997.

CAIXETA, R. P. et al. Variações genéticas em populações de Eucalyptus spp. detectadas por meio de marcadores moleculares. Revista Árvore, v.27, n.3, p.357-363, 2003.

FERREIRA, M.; SANTOS, P. E. T. Genetic improvement of Eucalyptus in Brazil - Brief review and propostectives. In: IUFRO CONFERENCE ON SILVICULTURE AND IMPROVEMENT OF EUCALYPTUS, 1997, Salvador. Proceedings... Salvador: 1997. v.1.p.14-34.

GAIOTTO, F. A.; BRAMUCCI, M.; GRATTAPAGLIA, D.Estimation of outcrossing rate in a breeding population of Eucalyptus urophylla with dominant RAPD and AFLP markers. Theoretical and Applied Genetics, v.95, n.5/6, p.842-849, 1997.

GRATTAPAGLIA, D.; BERTOLUCCI, F. L.; SEDEROFF, R. Genetic mapping of QTLs controlling vegetative propagation in Eucalyptus grandis and E. urophylla using a pseudotestcross strategy and RAPD markers.

Theoretical and Applied Genetics, v.90, n.7/8, p.933-947, 1995.

GRATTAPAGLIA, D.; SEDEROFF, R. Genetic linkage maps of Eucalyptus grandis and Eucalyptus urophylla using a pseudo-testcross: mapping strategy and RAPD markers. Genetics, v.137, n.4, p.1121-1137, 1994.

KREMER, A. et al. Molecular markers and genetics of forest trees. Biofutur, v.131, n.1, p.17-23, 1994.

LANGE, W. J.; WINGFIELD, B. D.; VILJOEN, C. D. RAPD-fingerprinting to identify Eucalyptus grandis clones. South African Forestry Journal, v. 167, n.1, p.47-50, 1993. 
MOURA, V. P. G. et al. Comportamento e resistência de procedências de eucalyptus grandis hill ex. maiden à formação de veios de "kino" em Planaltina, DF, área de cerrado. Boletim de Pesquisa Florestal, n.24/25, p.19-35, 1992.

MURO-ABAD, J. I. et al. Obtainment of Eucalyptus ssp. Hybrids aid by molecular markers - SSR analysis. Scientia Forestalis, n.67, n.1, p.53-63, 2005.

PIGATO, S. M. P. C.; LOPES, C. R. Avaliação da variabilidade genética em quatro gerações de Eucalyptus urophylla S.T. Blake por meio do marcador molecular RAPD. Scientia Forestalis, n.60, p.119-133, 2001.

MELLO, E. J.; ODA, S.; GILBERTONI, P. E. Seleção de progênies de Eucalyptus grandis à ocorrência de Puccinia psidii em condições de casa de vegetação. In: CONFERENCE ON SILVICULTURE AND IMPROVEMENT OF EUCALYPTUS, 1997. Salvador. Proceedings... Salvador: 1997. v.1. p.342-347.

NEWBURY, H. J.; FORD-LLOYD, B. V. The use of RAPD for assessing variation in plants. Plant Growth Regulator, v.12, n.1, p.43-51, 1993.
PHILLIPS, T. D.; MURPHY. J. P.; GOODMAN, M. $M$. Isozyme variation in germoplasm accession of the wild oat Avena sterilis L. Theoretical and Applied Genetics, v.86, n.1, p.54-64, 1993.

ROHLF, F. J. Relative warp analysis and an example of its application to mosquito wings. In: MARCUS, L. F.; BELLO, E.; GARCIAVALDECASAS, A. (Eds.). Contributions to morphometrics. Madrid: Museo Nacional de Ciências Naturales, 1993. v.8. p.131-159.

SEBBENN, A. M.; SEOANE, C. E. S. Estimativa de tamanho efetivo de endogamia por marcadores genéticos. Revista Árvore, v.29, n.1, p.1-8, 2005.

XAVIER, A.; COMÉRIO, J.; AUGUSTO, F. Eficiência da seleção massal em gerações $\mathrm{F}_{1}$ e $\mathrm{F}_{2}$ de Eucalyptus grandis Coff's Harbour. In: CONFERENCE ON SILVICULTURE AND IMPROVEMENT OF EUCALYPTUS, 1997, Salvador. Proceedings... Salvador: 1997.v.1. p.145-150.

WILLIAMS, J. G. K. et al. DNA polymorphisms amplified by arbitrary primers are useful as genetic markers. Nucleic Acids Resources, v.18, n.22, p.6531-6535, 1990. 